RIEG : EGH

II-3
DISPARTIEIT OF CORIERCE

NATIOIJAI BUREAU OF STAIJDARDS WASHINGTOIJ

(September 15, 1944)
Letter

Circular

LC -766

(Super'sedes (C-668)

MODERN BOOISS ON HOROLOGY

\title{
Contents
}

1. General Infomation

2. Historical and Descriptive Books

3. Technical Books

4. Governrent Publications

I. General Information

The purpose of this letter circular is to present a list of books which will be found valuable for the use of watchrakers, collectors, and others interested in tinepieces and in their performance and repair. IJo atter.pt has been made to include books earlier than 1900 or to list books in other than the English language, or nunerous articles published in trade journals and horological nagazines.

Sone of the books listed are obtainable fron dealers; sone, now unobtainable, can be found in public libraries. Price lists of books now on the narket nay be obtained from the watchnakers' supply dealers or fron the following:

The Anerican Horologist, 226 Sixteenth St., Denver, Colo. The Anerican Library Service, 117 West 48 th St., New York, N.Y. Henry Paulson \& Co., 37 South Wabash Ave., Chicago, Ill. Jewelers Circular - Keystone, Book Department, 100 East 42nd St., INew York, N. Y.

National Jeweler, 531 South LaSalle, St., Chicago, Ill.

Books not found at these sources nay often be found by advertising in the jewelers' trade journals.

A nore extensive list of references on tine, timepieces, and related subjects will be found in Tine and Timepieces by Wiliis I. Milhara, Appendix V, page: 569 (1923). 
2. Historical and Descriptive Bools

1. Time Telling Through the Ages - Harry C. Brearly Doubleday, Page \& Co., New York, N.X. 1920

2. Old Clocks and Watches and Their Hakers - F. J. Britten E.\& F. H. Spon, Ltd., London, England, 5th Ed. 1922

3. Time and Timepieces Inaclíilian CO., New York, N. Y.

Hillis I. Milham 1923

4. Time Measurement

D. Van Nostrand Co., Nev York, N. Y.

I. Bolton 1924

5. Clockmaking, Past and Present - G. F. O. Gordon iJorman W. Hensley Publishing Co., New York, N.Y. 1925

6. North Country Clockmakers of the 17th, 18th and 19th Centuries, Andrew Reid \& Co., Newcastie-on-Tyne, England

7. Watches

Rethuen \& Co., Ltd., London, Englend

G. H. Baillie 1929

8. Watchmakers and Clockmakers of the Woxld Methuen \& Co., Ltd. , London, England.

G. H. Baillie 1929

9. The Evolution of clock Work Casswell \& Co., Ltd., London, England

J. D. Robinson 1931

10. Old English Clocks St. Dominic's Press, London, England

F. H. Green 1931

11. The Lure of the clock New York University Press, New York, N. Y.

D. T. Hering 1932

12. Time Measurement

Part 1 Eistorical Review

Part 2 Descriptive Catalogue

Handbooks of the science siseum

His Hajesty's Stationery Office, London, England

13. Romance of the Calendar
W. Norton \& CO., Inc. NeV York, N. Y.

13. Romance of the Cal Norton \& Co., Inc., Nev York, $\bar{\Psi} . Y$.

P. W. Wilson

1936
1937

1937

14. Time and Its Mysteries - Hering, Swan, Dewey \& Compton James Arthur Foundation Lectures

Jew York university Press, Ilew York, N.Y. 
15. English Furniture and Clocks B. T. Batsford, Itd., London, England

R. T. Symonds 1940

16. Time and Its Reckoning - R. B.--Tay and N. D. Green Chemical Publishing Co., New York, N.Y. 1940

17. Its About Time - P. M. Chamberiain Mirs. P. M. Chamberlain, Keene, N.Y. 1941

\section{Technical Books}

18. The Balance Staff and Cylinder Hazlitt \& Walker, Chicago, IIl.

(Not now on the market)

P. V. Eigner 1903

19. Watch and Clock Escapements

Keystone Publishing Co., Philadelphia, Pa.

1904

20. Lessons in Horology

Keystone Publishing Co., Philadelphia, Pa. (translated from the German)

21. The Hodern Clock

Hazlitt \& Walker, Chicago, IIl.

- Tard L. Goodrich

1905

22. Compensating Pendulums

Hazlitt \& Walker, Chicago, III.

J. F. Finn and S. Riefler

1905

F. \& H. Grossman 
29. Watch ano ohronometer Jeveling

Hazlitt \& Walker, Chicago, Ill.

(Not now on the market)

- T. B. Sherrood

1921

30. Watch Repairing, Oleaning and Adjusting - F. J. Garrard

Crosley Lockmood \& Son, London, England 1922

31. Watoh and Clockmakers' Handbook - F. J. Britten

E. \& F. N. Spon, Ltd., London, England 1922

32. The Marine Chronometer - Rupert T. Gould

J. D. Potter, London, England

1923

33. Electric Horology - H. R. Langman and A. Ball

W. Hensley Publishing Co., Neri York, N.Y. 1923

34. Clock Repairing and Adjusting - T. I. Randall

Percival Marshall \& Co., London, England 1923

35. Watch Repairing and Adjusting - T. I. Randall

Percival Marshall \& Co., London, England 1923

36. Watchnskers' Handbook - Claudius Saunier

Crosley Lockrood \& Son, London, England 1924

(Translated by Tripplin and Rigg)

37. Practical Balance and Hairspring Jork - Walter J. Kleinlein

Jerelers Circular-Keystone, New York, N.Y. 1925

38. The Junior Watchmaker - A. G. Thisell

A. G. Thisell, Elgin; III.
(Deals with lever escapement adjusting)

1925

39. Modern Methods in Horology

Bradley Polytechnic Institute, Peoria, III. 1926

40. Horology - J. Eric Haswell

Chapman \& Hall, Ltd., London, England 1928

41. The Escepement and Trein of American Watches - T. J. Wilkinsor Jewelers Circular-Keystone, New York, N.Y. 1928

42. With the Watchmaker at the Sench - Donald Dedarle

I. Pitman \& Sons, Ltd., London, England 1933

43. Modern rethods in Watch Adjusting. - Harold C. Kelly

Harold C. Kelly, Spokane, Wash. 1933

44. lfodern Electric Clocks - S. F. Philpott

I. Iitman \& Sons, Ltd., London, England 1933 
45. llodern Clocks

Henry Paulson \& Co., Chicago, Ill.

R. R. Robinson

1935

46. Practical Benchwork for Horologists - Louis and Samuel Levin Levin \& Son, Los Angeles, Calif.

1938

47. Electrical Tinekeeping

N.A.G. Press, Ltd., London, Ingland

F. Hope-Jones

1940

48. Rules and Practice for Adjusting Watches - Valter J. Ileinlei. Jewelers Circular-Keystone, New York, N.Y.

Latest $\mathrm{id}$.

49. Mlodern Watch Repairing and Adjusting - John J. Bownan and E. Borer

Henry Paulson \& Co., Chicago, III. 1941

50. Aircraft Instruments

D. Van IJostrand Co., IJew York, I.Y.

D. E. Patton

1940 
The Hydrographic Office, Navy Department, publishes a tine zone nap of the world known as Tine zone Chart of the World, INo. 5192, which sells for 50 cents. This nap is $32 \times 40$ inches and is revised at frequent intervals.

Note: This list has been prepared in cooperation with Mr. John J. Bowran, Chairnan of the Tducational Connittee of the Horological Institute of Anerica. 